\title{
Currenti
}

\section{Confidentiality and privilege: What you don't know can hurt you}

\section{Understand the exception in divorce and child custody cases and inform patients accordingly}

$\mathrm{M}$ rs. W, age 35, presents to your clinic seeking treatment for anxiety and depression. She has no psychiatric history but reports feeling sad, overwhelmed, and stressed. Mrs. W has been married for 10 years, has 2 young children, and is currently pregnant. She recently discovered that her husband has been having an affair. Mrs. W tells you that she feels her marriage is unsalvageable and would like to ask her husband for a divorce, but worries that he will "put up a fight" and demand full custody of their children. When you ask why, she states that her husband is "pretty narcissistic" and tends to become combative when criticized or threatened, such as a recent discussion they had about his affair that ended with him concluding that if she were "sexier and more confident" he would not have cheated on her.

As Mrs. W is talking, you recall a conversation you recently overheard at a continuing medical education event. Two clinicians were discussing how their records had been subpoenaed in a child custody case, even though the patient's mental health was not contested. You realize that Mrs. W's situation may also fit under this exception to confidentiality or privilege. You wonder if you should have disclosed this possibility to her at the outset of your session and wonder what you should say now, because she is clearly in distress and in need of psychiatric treatment. On the other hand, you want her to be fully informed of the potential repercussions if she continues with treatment.

continued

Disclosures

The authors report no financial relationships with any companies whose products are mentioned in this article, or with manufacturers of competing products.

doi: $10.12788 /$ cp.0169

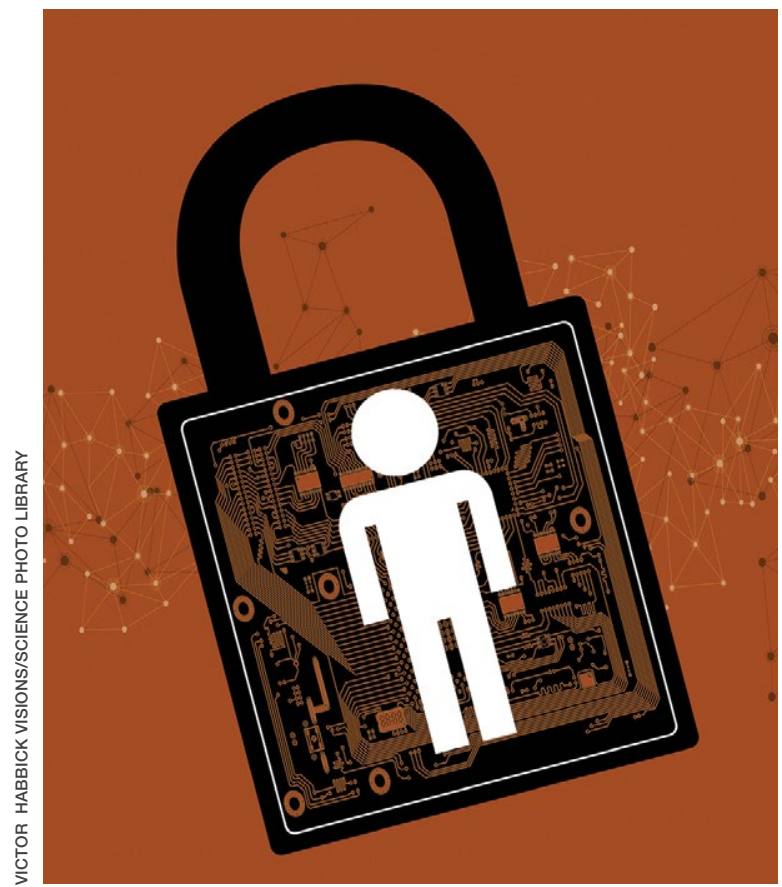

\section{Jacqueline S. Landess, MD, JD}

Assistant Clinical Professor Department of Psychiatry Medical College of Wisconsin Milwaukee, Wisconsin

\section{Kathleen L. Kruse, MD} Assistant Professor Department of Psychiatry Case Western Reserve University Cleveland, Ohio

\section{Shiri Raphaely, MD}

Child and Adolescent Psychiatry Fellow

University of Wisconsin-Madison Madison, Wisconsin

\section{Susan Hatters Friedman, MD}

The Phillip Resnick Professor of Forensic Psychiatry Professor of Reproductive Biology and Pediatrics

Adjunct Professor of Law Case Western Reserve University Cleveland, Ohio 


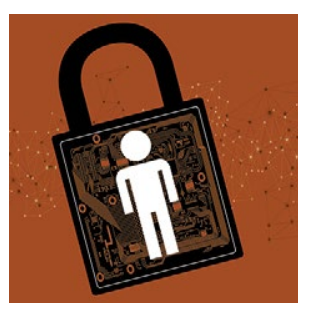

Confidentiality and privilege

\section{Clinical Point \\ In certain states, the mere filing of a child custody claim constitutes an exception to physician-patient privilege}

Discuss this article at www.facebook.com/ MDedgePsychiatry

\section{Table 1}

\section{Exceptions to confidentiality}

\begin{tabular}{lll} 
Exception & Description \\
$\begin{array}{l}\text { Duty to protect } \\
\text { third parties }\end{array}$ & $\begin{array}{l}\text { All states have exceptions, to varying degrees, with respect to duty to warn or } \\
\text { protect a third party in psychotherapeutic interactions. These statutes are based off } \\
\text { of the decision in Tarasoff } v \text { Regents of University of California }{ }^{2} \text { (1976), in which the } \\
\text { Supreme Court of California held that mental health professionals have a duty to } \\
\text { protect individuals who are being threatened with harm by a patient }\end{array}$ \\
$\begin{array}{ll}\text { Threats of } \\
\text { self-harm }\end{array}$ & $\begin{array}{l}\text { In the event of threats of self-harm or suicide, mental health professionals must take } \\
\text { and/or suicide }\end{array}$ & $\begin{array}{l}\text { of these statements to others to increase supports and potentially escalate provision } \\
\text { of mental health services, such as hospital admission for inpatient treatment }\end{array}$ \\
\hline $\begin{array}{l}\text { Child/vulnerable } \\
\text { adult protection }\end{array}$ & $\begin{array}{l}\text { In all states, there is an exception to confidentiality in cases where there is reason to } \\
\text { believe that a child or vulnerable adult has been subject to maltreatment, including }\end{array}$ \\
& $\begin{array}{l}\text { abuse or neglect. In these cases, the clinician is deemed a mandated reporter, and } \\
\text { is required by law to disclose information if there is suspicion of maltreatment }\end{array}$ \\
\hline $\begin{array}{l}\text { Public health } \\
\text { disclosures }\end{array}$ & $\begin{array}{l}\text { Clinicians must disclose diagnosis of certain medical conditions, including } \\
\text { communicable diseases and gun-related injuries, to local public health authorities to } \\
\text { prevent or control disease, injury, disability, and/or death of the population }\end{array}$ \\
\hline
\end{tabular}

Confidentiality and privilege allow our patients to disclose sensitive details in a safe space. The psychiatrist's duty is to keep the patient's information confidential, except in limited circumstances. The patient's privilege is their right to prevent someone in a special confidential relationship from testifying against them or releasing their private records. In certain instances, a patient may waive or be forced to waive privilege, and a psychiatrist may be compelled to testify or release treatment records to a court. This article reviews exceptions to confidentiality and privilege, focusing specifically on a littleknown exception to privilege that arises in divorce and child custody cases. We discuss relevant legislation and provide recommendations for psychiatrists to better understand how to discuss these legal realities with patients who are or may go through a divorce or child custody case.

\section{Understanding confidentiality and privilege}

Confidentiality and privilege are related but distinct concepts. Confidentiality relates to the overall trusting relationship created between 2 parties, such as a physician and their patient, and the duty on the part of the trusted individual to keep information private. Privilege refers to a person's specific legal right to prevent someone in that confidential, trusting relationship from testifying against them in court or releasing confidential records. Privilege is owned by the patient and must be asserted or waived by the patient in legal proceedings. The concepts of confidentiality and privilege are crucial in creating an open, candid therapeutic environment. Many courts, including the US Supreme Court, ${ }^{1}$ have recognized the importance of confidentiality and privilege in establishing a positive therapeutic relationship between a psychotherapist and a patient. Without confidentiality and privilege, patients would be less likely to share sensitive yet clinically important information.

Commonly encountered exceptions to confidentiality (Table $\mathbf{1}^{2}$ ) and privilege (Table 2, page 11) exist in medical practice. Psychiatrists should discuss these exceptions with patients at the outset of clinical treatment. A little-known exception to privilege that may compel a psychiatrist to disclose confidential records can occur in child custody proceedings. In certain states, the mere filing of a child custody claim constitutes an exception to physician-patient privilege. In these states, the parent filing for divorce and custody may automatically waive privilege and thus compel disclosure of psychiatric records, even if their mental health is not in question. The following 


\section{Exceptions to privilege}

\begin{tabular}{ll} 
Exception & Description \\
\hline $\begin{array}{l}\text { Civil commitment } \\
\text { proceedings }\end{array}$ & $\begin{array}{l}\text { In cases where a person requires involuntary psychiatric hospitalization for } \\
\text { treatment and safety management, privilege is waived for the purposes of legal } \\
\text { proceedings to hospitalize a patient. Such situations would include when, due to } \\
\text { mental illness, a person constitutes an immediate danger to themself or others }\end{array}$ \\
\hline Court evaluations & $\begin{array}{l}\text { If a court orders an evaluation of a person's physical or mental health, } \\
\text { communications conducted in the setting of this evaluation are not privileged }\end{array}$ \\
\hline Malpractice suits & If a person files a malpractice claim in civil proceedings against a clinician, that \\
& person waives their right to physician-patient privilege
\end{tabular}

recent Ohio Supreme Court case illustrates this exception.

\section{Friedenberg v Friedenberg (2020)}

Friedenberg $v$ Friedenberg ${ }^{3}$ addressed the issue of privilege and release of mental health treatment records in custody disputes. Belinda Torres Friedenberg and Keith Friedenberg were married with 4 minor children. Mrs. Friedenberg filed for divorce in 2016, requesting custody of the children and spousal support. In response, Mr. Friedenberg also filed a complaint seeking custody. Mr. Friedenberg subpoenaed mental health treatment records for Mrs. Friedenberg, who responded by filing a request to prevent the release of these records given physician-patient privilege. Mr. Friedenberg argued that Mrs. Friedenberg had placed her physical and mental health at issue when she filed for divorce and custody. At no point did Mr. Friedenberg allege that Mrs. Friedenberg's mental health made her an unfit parent. The court agreed with Mr. Friedenberg and compelled disclosure of Mrs. Friedenberg's psychiatric records, stating it is "hard to imagine a scenario where the mental health records of a parent would not be relevant to issues around custody and the best interests of the children." The judge reviewed Mrs. Friedenberg's psychiatric records privately and released records deemed relevant to the custody proceedings. On appeal, the Ohio Supreme Court agreed with this approach, holding that a parent's mental fitness is always an issue in child custody cases, even if not asserted by either party. The court further held that unnecessary disclosure of sensitive information was prevented by the judge's private review of records before deciding which records to release to the opposing spouse.

\section{Waiver of physician-patient privilege}

Waiver of physician-patient privilege in custody and divorce proceedings varies by state (Table $3{ }^{3-6}$ page 12). The Friedenberg decision highlights the most restrictive approach, where the mere filing of a divorce and child custody request automatically waives privilege. Some states, such as Indiana, ${ }^{4}$ follow a similar scheme to Ohio. Other states are silent on this issue or explicitly prohibit a waiver of privilege, asserting that custody disputes alone do not trigger disclosure without additional justifications, such as aberrant parental behaviors or other historical information concerning for abuse, neglect, or lack of parental fitness, or if a parent places their mental health at issue. ${ }^{7}$

Once privilege is waived, the next step is to determine who should examine psychiatric records, deem relevance, and disclose sensitive information to the court and the opposing party. A judge may make this determination, as in the Friedenberg case. Alternatively, an independent psychiatric examiner may be appointed by the court to examine one or both parties; to obtain collateral information, including psychiatric records; and to submit a report to the court with medicolegal opinions regarding parental fitness. For example, in Maryland, ${ }^{6}$ the mere filing of a custody suit does not waive privilege. If a parent's mental health is questioned, the judge may order an

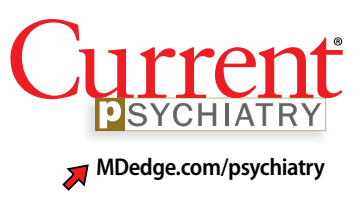

Clinical Point

In some states, if a parent's mental health is questioned, the judge may order an independent psychiatric examination 


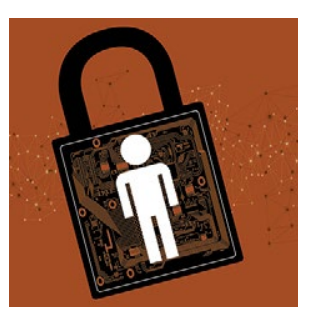

Confidentiality and privilege

\section{Clinical Point}

An automatic waiver policy may create an additional obstacle for individuals who are already reticent to seek treatment

\section{Examples of state case law regarding privilege in custody proceedings}

\begin{tabular}{|c|c|c|c|}
\hline Case & State & $\begin{array}{l}\text { Automatic } \\
\text { waiver? }\end{array}$ & $\begin{array}{l}\text { How is evidence introduced in } \\
\text { proceedings? }\end{array}$ \\
\hline $\begin{array}{l}\text { Friedenberg v Friedenberg }{ }^{3} \\
\text { Supreme Court of Ohio } \\
\text { (2020) }\end{array}$ & Ohio & Yes & $\begin{array}{l}\text { The judge conducts a private review of } \\
\text { records to determine release of relevant } \\
\text { records }\end{array}$ \\
\hline $\begin{array}{l}\text { Owen v Owen } \\
\text { Supreme Court of Indiana } \\
\text { (1991) }\end{array}$ & Indiana & Yes & $\begin{array}{l}\text { All records are subject to liberal discovery- } \\
\text { the judge conducts a private review of } \\
\text { records claimed to remain within privilege }\end{array}$ \\
\hline $\begin{array}{l}\text { People ex. Rel. Hickox } \\
\text { v Hickox } \\
\text { Appellate Division of the } \\
\text { Supreme Court of New York, } \\
\text { First Department (1978) }\end{array}$ & New York & No & $\begin{array}{l}\text { A Special Term Justice shall examine the } \\
\text { records and determine which (if any) parts of } \\
\text { the records shall be disclosed }\end{array}$ \\
\hline $\begin{array}{l}\text { Laznovsky } v \text { Laznovsky } \\
\text { Court of Appeals of } \\
\text { Maryland (2000) }\end{array}$ & Maryland & No & $\begin{array}{l}\text { The judge can order an independent } \\
\text { psychiatric examination of both parties }\end{array}$ \\
\hline
\end{tabular}

independent psychiatric examination to determine the parent's fitness, thus balancing the best interests of the child with the parent's right to physician-patient privilege.

\section{The problem with automatic waivers}

The foundation of the physician-patient relationship is trust and confidentiality. While this holds true for every specialty, perhaps it is even more important in psychiatry, where our patients routinely disclose sensitive, personal information in hopes of healing. Patients may not be aware of exceptions to confidentiality, or only be aware of the most well-known exceptions, such as the clinician's duty to report abuse, or to warn a third party about risk of harm by a patient. Furthermore, clinicians and patients alike may not be aware of less-common exceptions to privilege, such as those that may occur in custody proceedings. This is critically important in light of the high number of patients who are or may be seeking divorce and custody of their children.

As psychiatric clinicians, it is highly likely that we will see patients going through divorce and custody proceedings. In 2018, there were 2.24 marriages for every divorce, ${ }^{8}$ and in 2014, 27\% of all American children were living with a custodial parent, with the other parent living elsewhere. ${ }^{9}$
Divorce can be a profoundly stressful time; thus, it would be expected that many individuals going through divorce would seek psychiatric treatment and support.

Our concern is that the Friedenberg approach, which results in automatic disclosure of sensitive mental health information when a party files for divorce and custody, could deter patients from seeking psychiatric treatment, especially those anticipating divorce. Importantly, because women are nearly twice as likely as men to experience depression and anxiety ${ }^{10}$ and are more likely to seek treatment, this approach could disproportionately impact them. ${ }^{11}$ In general, an automatic waiver policy may create an additional obstacle for individuals who are already reticent to seek treatment.

\section{How to handle these situations}

As a psychiatrist, you should be familiar with your state's laws regarding exceptions to patient-physician privilege, and should discuss exceptions at the outset of treatment. However, you will need to weigh the potential negative impacts of this information on the therapeutic relationship, including possible early termination. Furthermore, this information may impact a patient's willingness to disclose all relevant information to mental health treatment if there is concern for later court 
disclosure. How should you balance these concerns? First, encourage patients to ask questions and raise concerns about confidentiality and privilege. ${ }^{12}$ In addition, you may direct the patient to other resources, such as a family law attorney, if they have questions about how certain information may be used in a legal proceeding.

Second, you should be transparent regarding documentation of psychiatric visits. While documentation must meet ethical, legal, and billing requirements, you should take care to include only relevant information needed to make a diagnosis and provide indicated treatment while maintaining a neutral tone and avoiding medical jargon. ${ }^{13}$ For instance, we frequently use the term "denied" in medical documentation, as in "Mr. X denied cough, sore throat, fever or chills." However, in psychiatric notes, if a patient "denied alcohol use," the colloquial interpretation of this word could imply a tone of distrust toward the patient. A more sensitive way to document this might be: "When screened, reported no alcohol use." If a patient divulges information and then asks you to omit this from their chart, but you do not feel comfortable doing so, explain what and why you must include the information in the chart. ${ }^{14}$

Third, if you receive a subpoena or other document requesting privileged information, first contact the patient and inform them of the request, and then seek legal consultation through your employer or malpractice insurer. ${ }^{15}$ Not all subpoenas are valid and enforceable, so it is important for an attorney to examine the subpoena; in addition, the patient's attorney may choose to challenge the subpoena and limit the disclosure of privileged information.

Finally, inform legislatures and courts about the potential harm of automatic waivers in custody proceedings. A judge's

\section{Related Resources}

- Legal Information Institute. Child custody: an overview. www.law.cornell.edu/wex/child_custody

- Melton GB, Petrila J, Poythress NG, et al. Child custody in divorce. In: Melton GB, Petrila J, Poythress NG, et al. Psychological evaluations for the courts. Guilford Press; 2018:530-533.

examination of the psychiatric records, as in Friedenberg, is not an adequate safeguard. A judge is not a trained mental health professional and may deem "relevant" information to be nearly everything: a history of abuse, remote drug or alcohol use, disclosure of a past crime, or financial troubles. We advocate for courts to follow the Maryland model, where a spouse does not automatically waive privilege if filing for divorce or custody. If mental health becomes an issue in a case, then the court may seek an independent psychiatric examination. The independent examiner will have access to patient records but will be in a better position to determine which details are relevant in determining diagnosis and parental fitness, and to render an opinion to the court.

\section{CASE CONTINUED}

You inform Mrs. W about a possible exception to privilege in divorce and custody cases. She decides to first talk with a family law attorney before proceeding with treatment. You defer your diagnosis and wait to see if she wants to proceed with treatment. Unfortunately, she does not return to your office.

\footnotetext{
References

1. Jaffee $v$ Redmond, 518 US 1 (1996).

2. Tarasoff $\mathrm{v}$ Regents of the University of California, $118 \mathrm{Cal}$ Rptr 129 (Cal 1974); modified by Tarasoff $\mathrm{v}$ Regents of the Univ. of Cal., 551 P.2d 334 (Cal 1976).

3. Friedenberg v Friedenberg, No. 2019-0416 (Ohio 2020).

4. Owen v Owen, 563 NE 2d 605 (Ind 1991).
}

continued on page 60

\section{Bottom Line}

Some states limit the confidentiality and privilege of parents who are in psychiatric treatment and also involved in divorce and child custody cases. Psychiatrists should be mindful of these exceptions, and discuss them with patients at the onset of treatment.

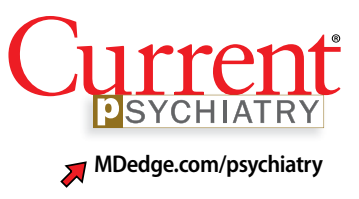

Clinical Point

If you receive

a subpoena

requesting privileged information, first inform the patient, and then seek legal consultation 


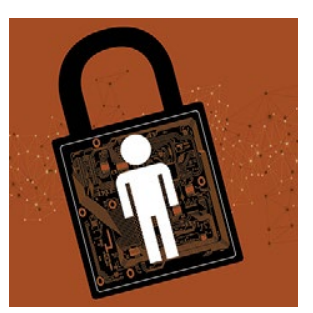

Confidentiality and privilege

\section{Clinical Point}

Inform legislatures and courts about the potential harm of automatic waivers in custody proceedings
Confidentiality and privilege

continued from page 13

5. People ex. Rel. Hickox v Hickox, 410 NY S 2d 81 (NY App Div 1978).

6. Laznovsky v Laznovsky, 745 A 2d 1054 (Md 2000).

7. Eykel I, Miskel E. The mental health privilege in divorce and custody cases. Journal of the American Academy of Matrimonial Lawyers. 2012;25(2):453-476.

8. Center for Disease Control and Prevention. FastStats: Family life. Marriage and divorce. Published May 2020. Accessed July 29, 2021. www.cdc.gov/nchs/fastats/ marriage-divorce.htm

9. The United States Census Bureau. Current population reports: custodial mothers and fathers and their child support: 2013. Published January 2016. Accessed July 29, 2021. https://www.census.gov/content/dam/Census/ library/publications/2016/demo/P60-255.pdf

10. World Health Organization. Gender and mental health Published June 2002. Accessed August 2, 2021. https:// www.who.int/gender/other_health/genderMH.pdf
11. Wang PS, Lane M, Olfson M, et al. Twelve-month use of mental health services in the United States: results from the National Comorbidity Survey Replication. Arch Gen Psychiatry. 2005;62(6):629-640.

12. Younggren J, Harris E. Can you keep a secret? Confidentiality in psychotherapy. J Clin Psychol. 2008; 64(5):589-600.

13. The Committee on Psychiatry and Law. Confidentiality and privilege communication in the practice of psychiatry. Report no. 45. Group for the Advancement of Psychiatry; 1960.

14. Wiger D. Ethical considerations in documentation. In: Wiger D. The psychotherapy documentation primer. 3rd ed. Wiley; 2013:35-45.

15. Stansbury CD. Accessibility to a parent's psychotherapy records in custody disputes: how can the competing interests be balanced? Behav Sci Law. 2010;28(4): 522-541. 